\title{
PENGARUH EMPLOYEE ENGAGEMENT, PEMBERDAYAAN, DAN KOMITMEN ORGANISASI TERHADAP KINERJA KARYAWAN PT. TOYOTA MOTORMANUFACTURING INDONESIA
}

\author{
Adel Christian P Sakeru, Aji Hermawan, \& Yunus Triyonggo \\ Program Magister Manajemen Bisnis, Sekolah Bisnis, Institut Pertanian Bogor \\ E-mail: christianadel612@gmail.com
}

\begin{abstract}
ABSTRAK
PT Toyota Motor Manufacturing Indonesia perlu memiliki SDM yang berkualitas dan kompeten untuk menghadapi persaingan yang ketat dan pertumbuhan perusahaan sejenis. Pengembangan SDM perlu dilakukan secara baik dan terencana, diantaranya dengan melakukan evaluasi employee engagement, pemberdayaan dan komitmen organisasi agar kinerja karyawan dapat terus ditingkatkan. Tujuan penelitian ini adalah menganalisis pengaruh employee engagement, pemberdayaan dan komitmen organisasi terhadap kinerja karyawan divisi human resource PT. Toyota Motor Manufacturing Indonesia. Metode analisis data yang digunakan adalah Structural Equation Model (SEM) dengan metode Partial Least Squares (PLS) yang menggunakan software SmartPLS. Hasil dari penelitian ini adalah pemberdayaan dan komitmen organisasi berpengaruh signifikan dan berpengaruh positif terhadap kinerja karyawan. Selain itu employee engagement dan pemberdayaan berpengaruh signifikan dan berpengaruh positif terhadap komitmen organisasi. Employee engagement tidak berpengaruh signifikan, namun memiliki pengaruh yang positif terhadap kinerja karyawan. Hal ini menunjukkan bahwa employee engagement tidak memberikan pengaruh langsung, namun memberikan pengaruh tidak langsung terhadap kinerja karyawan melalui komitmen organisasi.
\end{abstract}

Kata kunci: employee engagement, pemberdayaan, komitmen organisasi, kinerja karyawan Klasifikasi JEL: M540

\begin{abstract}
PT Toyota Motor Manufacturing Indonesia needs to possess quality and competent human resources in order to face the stiff competition with the continuous growth of similar companies. Human resources development in a company must be well performed and well planned, and one way to do so is by performing evaluations about employee engagement, empowerment, and organisational commitment so that employees' performance can be improved continuously, which in turn will improve the employees' prosperity and the company's profit. The purpose of this research is to analyse the impact of employee engagement, empowerment, and organisational commitment on the employees of PT. Toyota Motor Manufacturing, Indonesia's human resources division. The data analysis method utilised in this research is the Structural Equation Model (SEM) with the Partial Least Squares (PLS) method, which uses the SmartPLS software. The result of this research is that empowerment and organisational commitment have a significant and positive impact on employees' performance. Furthermore, employee engagement and empowerment also have a significant and positive result on organisational commitment. Employee engagement does not have a significant impact on employee performance, but it has a positive impact on employee performance. It shows that employee engagement does not have a direct impact, but it has an indirect impact on employee performance through organisational commitment.
\end{abstract}

Keywords: employee engagement, empowerment, organizational commitment, employee performance

JEL Classification: M540 


\section{Adel Christian P Sakeru \\ Aji Hermawan \\ Yunus Triyonggo \\ PENDAHULUAN}

Saat ini terjadi persaingan yang ketat antar perusahaan-perusahaan yang ada di dunia. Perusahaan harus mampu mempertahankan aset-aset yang dimiliki untuk menghadapi persaingan yang ketat tersebut. Salah satu aset yang sangat penting untuk diperhatikan adalah sumber daya manusia. Sirait (2006) menyatakan bahwa sasaran yang ingin dicapai pihak manajemen sumber daya manusia adalah terciptanya kondisi dimana karyawan dapat mencapai produktivitas yang tinggi dan karyawan mampu bertahan. Apabila hal ini tercipta, maka dapat dikatakan bahwa pekerjaan pihak manajemen sumber daya manusia sudah efektif.

Banyak permasalahan seputar manajemen sumber daya manusia yang menyebabkan organisasi mengalami kemunduran, permasalahan yang timbul dapat disebabkan salah satunya oleh penurunan kinerja karyawan. Menurut Mangkunegara (2007), penurunan kinerja karyawan dipengaruhi oleh banyak faktor seperti upah atau gaji yang diterima, kesempatan pengembangan karir, hubungan dengan karyawan lain, penempatan kerja, jenis pekerjaan, struktur organisasi dan lain sebagainya. Permasalahan-permasalahan tersebut perlu diperhatikan karena secanggih apapun teknologi yang dipergunakan dalam organisasi serta sebesar apapun modal organisasi, karyawan dalam organisasilah yang pada akhirnya yang akan menjalankan sistem tersebut. Hal ini menunjukkan bahwa tanpa didukung dengan kualitas karyawan yang baik, keberhasilan dari sebuah organisasi tidak akan tercapai.

Kontribusi karyawan pada suatu organisasi akan menentukan maju atau mundurnya sebuah organisasi. Kontribusi karyawan pada organisasi akan menjadi penting jika dilakukan dengan tindakan efektif dan berperilaku secara benar. Setiap karyawan perlu mengetahui dengan pasti apa yang menjadi tanggung jawab utamanya, kinerja seperti apa yang harus dicapainya serta dapat mengukur sendiri sesuai indikator keberhasilannya. Terdapat banyak hal yang menjadi perhatian pihak manajemen guna mendorong kinerja karyawan diantaranya dalam kaitannya dengan employee engagement, pemberdayaan dan komitmen organisasi.

Menurut Rivai (2005) kinerja adalah tingkat keberhasilan seseorang secara keseluruhan selama periode tertentu di dalam melaksanakan tugas dibandingkan dengan berbagai kemungkinan seperti standar hasil kerja dan target yang telah ditentukan terlebih dahulu dan telah disepakati bersama. Mangkuprawira dan Hubeis (2007) menyatakan kinerja merupakan hasil dari proses pekerjaan tertentu secara terencana pada waktu dan tempat tertentu dari karyawan serta perusahaan bersangkutan. Organisasi atau perusahaan dianggap sangat perlu untuk mengelola faktor-faktor yang mempengaruhi kinerja karyawan 
agar karyawan dapat memperoleh hasil kerja yang sesuai dengan standar yang telah ditetapkan oleh perusahaan. Adapun pada penelitian ini faktor-faktor yang dianggap mempengaruhi kinerja karyawan adalah keterlekatan karyawan, pemberdayaan dan komitmen organisasi.

Banyak kalangan berpendapat bahwa employee engagement harus menjadi perhatian serius oleh pihak eksekutif puncak agar perusahaannya dapat bertahan dari fenomena turnover yang tinggi. Employee engagement merupakan salah satu cara untuk membuat karyawan memiliki loyalitas yang tinggi. Macey dan Schneider (2008) menyatakan bahwa, employee engagement dapat membuat karyawan memiliki loyalitas yang lebih tinggi, sehingga mengurangi keinginan untuk meninggalkan perusahaan secara sukarela. Schaufeli et al. (2002) menyatakan employee engagement berkaitan dengan pekerjaan yang ditandai oleh kesungguhan (vigor), dedikasi (dedication) dan penghayatan (absorption). Employee engagement juga mengacu pada kondisi perasaan dan pemikiran konsisten yang tidak hanya berfokus pada objek dan perilaku tertentu. Employee engagement dianggap dapat memberikan informasi mengenai tingkat employee engagement terhadap faktor organisasi. Faktor ini mendorong karyawan untuk melakukan usaha yang maksimal melebihi dari yang diharapkan. Hal tersebut pada akhirnya akan berperan pada tingkat kemajuan kinerja individu dan kinerja perusahaan.

Hasil penelitian Aon Hewitt (2010) menyatakan bahwa terdapat korelasi yang kuat antara employee engagement dengan kinerja perusahaan. Perusahaan dengan indeks employee engagement yang tinggi ( $65 \%$ ke atas), selalu berhasil melampaui indeks bursa saham dan menghasilkan tingkat pengembalian bagi para pemegang saham sebesar $22 \%$ lebih tinggi dibandingkan rata-rata. Sebaliknya perusahaan dengan indeks employee engagement yang lebih rendah ( $45 \%$ ke bawah), menghasilkan pengembalian $28 \%$ lebih rendah dari rata-rata untuk para pemegang saham. Penelitian ini juga menemukan bagaimana organisasi membuat perbedaan dan meraih keunggulan kompetitif melalui sumber daya manusianya. Hal ini dapat dilihat dari adanya tingkat employee engagement yang tinggi seperti meningkatnya retensi dan produktifitas, menghasilkan tingkat turnover yang rendah, talent pool yang besar dan kinerja bisnis yang baik.

Menurut Spreitzer (1996), pemberdayaan adalah cara orang memandang diri mereka sendiri di dalam lingkungan kerja dan tingkat sejauh mana orang merasa mampu untuk membentuk peran kerja. Noe et al. (2003) menambahkan bahwa pemberdayaan adalah pemberian tanggung jawab dan wewenang terhadap pekerja untuk mengambil keputusan menyangkut semua pengembangan produk dan pengambilan keputusan. Pemberdayaan karyawan harus mendapatkan dukungan penuh dari manajemen puncak. Perusahaan 
Adel Christian P Sakeru

Aji Hermawan

\section{Yunus Triyonggo}

perlu memberikan bekal tambahan untuk meningkatkan kemampuan karyawan. Pemberdayaan merupakan simbol perilaku kolektif kelompok dan kebijakan organisasi sehingga diperlukan visi yang jelas dan dinamis dari organisasi untuk karyawan dan manajer secara berkesinambungan (Abadi \& Chegini, 2013). Persaingan yang semakin ketat antar perusahaan mendorong organisasi untuk membuat kebijakan yang mendukung pemberdayaan karyawan. Pemberdayaan karyawan mencakup dua pokok persoalan yang amat penting dalam meningkatkan kinerja perusahaan yakni konsep pemberdayaan yang berakar komitmen dan kepercayaan pegawai sebagai suatu strategi dalam menjalankan perusahaan (Batliwala, 2007).

Pemberdayaan karyawan menjadi penting karena dalam menghadapi persaingan dan pelayanan, karena setiap organisasi membutuhkan karyawan yang cepat tanggap dan mandiri sehingga organisasi mempunyai keunggulan kompetitif melalui sumber daya manusianya. Pemberdayaan oleh perusahaan digunakan sebagai sarana untuk memperkuat kapabilitas dan komitmen karyawan. Tujuan dari pemberdayaan yaitu untuk memunculkan potensi dan modalitas yang ada pada diri karyawan dan memaksimalkannya sehingga karyawan menjadi mandiri dan dapat meningkatkan kinerjanya. Pada akhirnya pemberdayaan dapat memberikan nilai manfaat bagi karyawan dan organisasi. Pemberdayaan karyawan juga membantu karyawan untuk merasa bahwa kontribusi mereka mempunyai arti, bahwa mereka berkompeten dan mereka mempunyai pilihan terhadap apa yang dikerjakan. Pemberdayaan membantu karyawan untuk menambah kontrol terhadap kinerja mereka dan penanggulangan yang lebih baik terhadap stres. Karyawan yang dilibatkan dalam proses perencanaan dan pengambilan keputusan akan membuat karyawan merasa diperlukan secara adil dalam menjadi bagian dari kontributor keberhasilan perusahaan. Boudrias et al. (2010) menyatakan seorang atasan yang memberdayakan praktik manajerial dan pemberdayaan perilaku karyawan akan membuat karyawan merasakan tingkat keadilan yang tinggi di dalam lingkungan kerja.

Indikator lain yang dapat meningkatkan kinerja karyawan adalah komitmen organisasi. Karyawan dengan komitmen yang tinggi diharapkan mampu menghasilkan kinerja yang optimal. Saat seseorang bergabung dalam organisasi, maka karyawan tersebut dituntut untuk memiliki komitmen di dalam dirinya. Tingkat komitmen baik komitmen perusahaan terhadap karyawan, maupun antara karyawan terhadap perusahaan sangat diperlukan karena melalui komitmen-komitmen tersebut akan tercipta iklim kerja yang profesional. Komitmen organisasi adalah suatu keadaan dimana seorang karyawan memihak kepada organisasi tertentu serta tujuan dan keinginannya untuk mempertahankan keanggotaan dalam organisasi tersebut. Luthans (2007) menyatakan bahwa komitmen organisasi adalah 
sikap yang menunjukkan loyalitas karyawan dan merupakan proses berkelanjutan seseorang dalam mengekspresikan perhatiannya untuk kesuksesan organisasi.

Allen dan Meyer (1990) menyatakan bahwa, komitmen organisasi terdiri dari tiga komponen yaitu komitmen afektif (affective commitment), komitmen berkelanjutan (continuance commitment) dan komitmen normatif (normative commitment). Tiga komponen komitmen ini sangat penting dan strategis tidak saja demi kelangsungan dan pengembangan organisasi, tetapi juga bagi karyawan dalam meningkatkan kinerjanya. Komitmen organisasi yang tinggi akan menyebabkan karyawan cenderung memiliki dedikasi yang tinggi dalam bekerja. Hal ini akan sangat membantu karyawan dalam menunjukkan kinerja terbaiknya, yang pada akhirnya dengan menghasilkan kinerja terbaik tersebut maka karyawan akan berpeluang untuk memperoleh promosi jabatan. Hal ini menunjukkan bahwa eksistensi komitmen organisasi memang sangat strategis bagi kepentingan organisasi dan karyawan.

Chughtai dan Zafar (2006) menyatakan semakin tinggi komitmen organisasi maka akan semakin tinggi pula kecenderungan seseorang untuk diarahkan pada tindakan yang sesuai dengan standar kinerja karyawan. Hal ini didukung oleh penelitian sebelumnya yang dilakukan Fitriastuti (2011) dan Tolentino (2013) yang menyatakan bahwa komitmen organisasi sangat besar pengaruhnya terhadap kinerja seseorang. Seorang karyawan akan bekerja secara maksimal dan memanfaatkan kemampuan serta keterampilannya dengan bersemangat ketika karyawan memiliki komitmen organisasi yang tinggi. Sifat dari komitmen organisasi dapat berubah sepanjang waktu.

Mengingat pentingnya peran sumber daya manusia employee engagement, pemberdayaan, komitmen organisasi dan kinerja karyawan maka perusahaan harus dapat menerapkan faktor-faktor tersebut dengan baik untuk keberhasilan usaha perusahaan. Perusahaan PT Toyota Motor Manufacturing Indonesia adalah perusahaan yang bergerak dalam bisnis manufaktur dan eksportir kendaraan bermotor. Perusahaan ini perlu memiliki sumber daya manusia yang berkualitas dan kompeten untuk menghadapi persaingan yang ketat dan pertumbuhan perusahaan sejenis. Penelitian ini dilakukan pada divisi human resource. Divisi human resource memiliki peran yang sangat penting dalam keberlangsungan dari sebuah perusahaan. Salah satu fungsi dari divisi ini adalah melakukan rekrutmen terhadap calon karyawan yang akan bergabung dengan perusahaan. Caloncalon karyawan tersebut harus memiliki kualifikasi yang sesuai dengan kebutuhan organisasi. Fungsi lain dari divisi ini adalah melakukan pelatihan dan pengembangan terhadap karyawan, sehingga karyawan-karyawan tersebut kelak dapat memberikan kontribusi yang baik kepada perusahaan. Pengembangan sumber daya manusia di perusahaan ini perlu dilakukan secara baik dan terencana, diantaranya dengan melakukan evaluasi employee 
Adel Christian P Sakeru

Aji Hermawan

\section{Yunus Triyonggo}

engagement, pemberdayaan dan komitmen organisasi agar kinerja karyawan dapat terus ditingkatkan dan pada akhirnya dapat meningkatkan kesejahteraan karyawan serta keuntungan perusahaan. Evaluasi employee engagement, pemberdayaan dan komitmen organisasi terhadap kinerja karyawan pada divisi human resource PT. Toyota Motor Manufacturing Indonesia juga belum pernah dilakukan.

Berdasarkan uraian di atas, maka perlu dilakukan analisis pengaruh employee engagement, pemberdayaan dan komitmen organisasi terhadap kinerja karyawan. Selanjutnya, berdasarkan hasil analisis tersebut dapat dilihat implikasi peningkatan kinerja sumber daya manusia karyawan divisi human resource PT Toyota Motor Manufacturing Indonesia dengan memanfaatkan hubungan faktor-faktor tersebut. Tujuan penelitian ini adalah menganalisis pengaruh keterlekatan karyawan, pemberdayaan dan komitmen organisasi terhadap kinerja karyawan divisi human resource PT. TMMIN.

\section{TINJAUAN PUSTAKA}

\section{Keterlekatan Karyawan}

Macey dan Scheneider (2008) menjelaskan keterlekatan karyawan sebagai perasaan individu terhadap sebuah tujuan dan energi terfokus, jelas bagi orang lain dalam tampilan inisiatif pribadi, kemampuan beradaptasi, usaha dan ketekunan yang diarahkan pada tujuan organisasi. Definisi lain mengenai keterlekatan karyawan adalah keterlekatan sebagai sesuatu energi yang positif, pekerjaan yang berhubungan dengan keadaan pikiran yang ditandai dengan semangat, dedikasi dan berinisiatif (Schaufeli et al., 2002).

Keterlekatan karyawan merupakan bentuk-bentuk perilaku kerja karyawan yang dapat membantu manajemen dalam mencapai target kinerja perusahaan. Menurut Kreitner dan Kinicki (2010), terdapat beberapa jenis perilaku yang mirip dengan konsep keterlekatan karyawan seperti organizational commitment, organizational citizenship behavior dan job satisfaction. Organizational citizenship behavior (OCB) adalah perilaku karyawan yang melebihi apa yang diharapkan oleh perusahaan. Sementara itu, organizational commitment menggambarkan sejauh mana karyawan memilih untuk bersama organisasinya dan berkomitmen untuk mencapai tujuan-tujuan perusahaan. Kepuasan kerja menggambarkan sejauh mana karyawan menyukai pekerjaannya. Saat ini, keterlekatan karyawan dianggap sebagai kondisi psikologis (involvement, commitment dan mood), performance construct (organizational citizenship behavior dan positive affect) atau kombinasi dari dua unsur tersebut (Macey \& Scheneider, 2008).

Menurut Schaufeli et al. (2002), terdapat tiga dimensi dari keterlekatan karyawan yaitu: (1) Vigor atau semangat adalah karakter karyawan yang memiliki energi tinggi, memiliki 
kemauan bekerja atau semangat kerja tinggi, tidak mudah lelah, keinginan memberikan usaha terhadap pekerjaan dan ketahanan menghadapi kesulitan. (2) Dedication atau pengabdian adalah karakter karyawan yang memiliki keterkaitan yang kuat dengan pekerjaannya, memiliki rasa antusias, menginspirasi, memiliki kebanggaan dan menyukai tantangan. (3) Absorption atau inisiatif adalah karakter karyawan yang menikmati pekerjaannya, berkonsentrasi penuh dalam bekerja dan senang ketika terlibat dalam pekerjaan, waktu terasa berjalan cepat meskipun karyawan sedang menghadapi masalah.

\section{Pemberdayaan}

Menurut Spreitzer (1996) pemberdayaan adalah cara orang memandang diri mereka sendiri di dalam lingkungan kerja dan tingkat sejauh mana orang merasa mampu untuk membentuk peran kerja. Pemberdayaan adalah hubungan antar personal yang berkelanjutan untuk membangun kepercayaan antara pihak manajemen dengan karyawan. Pemberdayaan sangat erat hubungannya dengan profesionalisme yang pada awalnya selalu dimiliki oleh individual. Pemberdayaan juga dapat diartikan sebagai sebuah konsep yang menggambarkan tentang bagaimana organisasi mampu mengoptimalkan sumber daya manusia sesuai dengan kemampuan dan kapasitasnya. Pemberdayaan dapat memulihkan dan mengembangkan nilai tambah bagi perusahaan dan karyawan. Batliwala (2007) menyatakan bahwa pemberdayaan adalah sebuah konsep untuk meningkatkan kepuasan kerja dengan memadukan nilai-nilai sosial, sehingga karyawan senang dalam bekerja.

Konteks mengenai pemberdayaan sangat luas karena itu dalam konteks bisnis, Spreitzer (1996)menyatakan bahwa perspeksif psikologis fokus pada persepsi pemberdayaan yang dimiliki karyawan. Pemberdayaan psikologis merupakan variabel yang merefleksikan atau mencerminkan tingkatan pemberdayaan yang dirasakan karyawan. Menurut Spreitzer (1996) membagi pemberdayaan psikologis menjadi empat faktor :

1. Makna (meaning)

Nilai dari sebuah tujuan pekerjaan yang dicapai oleh seorang individu sehubungan dengan idealisme atau standar individu tersebut.

2. Berkompetensi/yakin pada kemampuan sendiri (competence/self-efficacy) Keyakinan yang dimiliki karyawan terhadap kemampuannya untuk melaksanakan tugas atau pekerjaan sesuai atau berdasarkan keahlian yang dimilikinya.

3. Penentuan sendiri/pilihan (self- determination)

Mengacu pada persepsi karyawan terhadap otonomi yang dimilikinya dalam memprakarsai dan mengatur tindakannya dalam pekerjaan. 
Adel Christian P Sakeru

Aji Hermawan

Yunus Triyonggo

4. Dampak (impact)

Seberapa besar pengaruh hasil pekerjaan yang dilakukan seorang karyawan di dalam sebuah lingkungan kerja.

Menurut Spreitzer (1995), pemberdayaan karyawan menimbulkan beberapa konsekuensi yang signifikan yakni berupa efektifitas dan tingkah laku inovatif. Pada level manajerial, pemberdayaan karyawan mampu memberikan kontribusi yang signifikan. Manajer yang diberdayakan akan melihat dirinya kompeten dan mampu mempengaruhi pekerjaan dan lingkungan kerjanya dengan cara yang berarti. Mereka juga lebih proaktif dalam melaksanakan tanggung jawab pekerjaannya, misalnya dalam mengantisipasi persoalan dan bertindak secara independen, sehingga pekerjaannya dapat dijalankan secara efektif. Selain itu, pemberdayaan akan mampu meningkatkan konsentrasi, inisiatif dan fleksibel, sehingga mendorong efektifitas kerja seorang manajer. Sedangkan pada level karyawan, jika karyawan diberdayakan, maka akan memiliki keyakinan bahwa mereka mampu melakukan sendiri dan mempunyai pengaruh, sehingga mereka cenderung lebih kreatif. Mereka tidak merasa terikat oleh peraturan atau aspek teknis pekerjaan. Keyakinan akan kemampuannya melakukan tugas akan mendorong karyawan untuk lebih inovatif dan mengharapkan dirinya berhasil.

\section{Komitmen Organisasi}

Robbins dan Judge (2011) menjelaskan definisi komitmen organisasi sebagai suatu keadaan dimana seorang karyawan memihak organisasi tertentu serta tujuan-tujuan dan keinginannya untuk mempertahankan keanggotaan dalam organisasi tersebut. Menurutnya keterlibatan pekerjaan yang tinggi berarti memihak pada pekerjaan tertentu seorang individu, sementara komitmen organisasi yang tinggi berarti memihak organisasi yang merekrut individu tersebut. Komitmen karyawan terhadap organisasi sangat penting, sebab tanpa komitmen yang kuat pegawai hanya akan bertindak sebagai oportunis. Komitmen organisasional (organizational commitment) adalah semacam sikap yang mencerminkan keterikatan seorang individu dengan organisasi tertentu dalam hal identifikasi dengannya atau keterlibatan di dalamnya.

Komitmen organisasi juga dapat diartikan sebagai keinginan dan loyalitas pekerja berpikir kearah organisasi. Lebih lanjut Robbins dan Judge (2015) mengemukakan pendapatnya terkait dengan komitmen organisasi, bahwa tiga dimensi terpisah komitmen organisasional adalah (1.) Komitmen afektif adalah perasaan emosional untuk organisasi dan keyakinan dalam nilai-nilainya, (2.) Komitmen berkelanjutan adalah nilai ekonomi yang dirasa dari bertahan dalam suatu organisasi bila dibandingkan dengan meninggalkan organisasi 
tersebut, (3.) Komitmen normatif adalah kewajiban untuk bertahan dalam organisasi untuk alasan-alasan moral atav etis.

Allen dan Meyer (1990) menyatakan bahwa, komitmen organisasi didefinisikan sebagai hubungan psikologi antara pekerja dan organisasiyang membuat pekerja enggan untuk meninggalkan organisasi. Allen dan Meyer (1990) membagi komitmen organisasi dalam tiga komponen, yaitu (1) komitmen afektif (affective commitment), (2) komitmen berkelanjutan (continuance commitment) dan (3) komitmen normatif (normative commitment). Komitmen afektif memiliki hubungan yang lebih erat dengan hasil-hasil organisasi seperti kinerja dan perputaran karyawan bila dibandingkan dengan dua dimensi komitmen lainnya. Pegawai yang memiliki komitmen afektif telah mengembangkan ikatan personal yang kuat dan ingin tetap menjadi bagian dari organisasi secara keseluruhan. Komitmen berkelanjutan didasarkan pada kebutuhan nyata untuk tetap bertahan meskipun mungkin terdapat hal tidak menyenangkan dalam organisasi tersebut. Pegawai semacam ini mungkin tidak bisa pindah ke tempat lain atau tuntutan keluarga yang menyebabkan karyawan harus tetap bertahan agar nyaman. Mungkin saja mereka tidak dapat menemukan hal yang lebih baik dan tidak ingin berhenti meskipun itu bukan merupakan situasi yang ideal. Pegawai yang memiliki komitmen normatif memberikan respon kepada organisasi dengan loyalitas dan keadilan. Organisasi telah memberikan pekerjaan bagi pegawai tersebut yang memungkinkan untuk menopang diri dan keluarganya, maka mereka merasa berhutang budi kepada organisasi untuk tetap berkarya. Individu dengan komitmen normatif yang tinggi akan tetap bertahan dalam organisasi karena merasa adanya suatu kewajiban atau tugas.

\section{Kinerja Karyawan}

Mangkunegara (2006) menyatakan, kinerja adalah hasil kerja secara kualitas dan kuantitas yang dicapai oleh seorang karyawan dalam melaksanakan tugasnya sesuai dengan tanggung jawab yang diberikan kepadanya. Secara umum dapat dikatakan bahwa kinerja merupakan wujud atau keberhasilan pekerjaan seseorang atau organisasi dalam mencapai tujuannya. Kinerja karyawan juga didefinisikan sebagai kemampuan pegawai dalam melakukan sesuatu keahlian tertentu (Sinambela, 2012). Maarif dan Kartika (2013) menjelaskan kinerja sebagai keluaran (result) yang merupakan real value bagi perusahaan, misalnya berupa jumlah penjualan, jumlah produksi, tingkat kualitas, efisiensi biaya, profit, dan sebagainya.

Simanjuntak (2011) menjelaskan bahwa yang dimaksud dengan kinerja karyawan adalah sebagai tingkat pencapaian hasil atas pelaksanaan tugas tertentu oleh seorang karyawan. Lebih lanjut lagi Mangkuprawira (2011) menggambarkan kinerja karyawan sebagai sesuatu 
Adel Christian P Sakeru

Aji Hermawan

Yunus Triyonggo

yang diartikan sebagai hasil atau tingkat keberhasilan seseorang secara keseluruhan selama periode tertentu di dalam melaksanakan tugas yang dibandingkan dengan berbagai kemungkinan, seperti standar hasil kerja, target, atau sasaran kriteria yang telah ditentukan terlebih dahulu dan telah disepakati bersama. Kinerja karyawan menjadi sangat penting, sebab dengan kinerja ini akan diketahui seberapa jauh kemampuan karyawan dalam melaksanakan tugas yang dibebankan kepadanya. Untuk itu diperlukan penentuan kriteria yang jelas dan terukur serta ditetapkan secara bersama-sama yang nantinya akan diajukan sebagai acuan.

Menurut Nawawi (2006), kinerja karyawan adalah hal-hal yang dikerjakan dan tidak dikerjakan oleh seorang karyawan di dalam melaksanakan tugas-tugas pokoknya. Indikator kinerja dalam melaksanakan pekerjaan di dalam suatu lingkungan perusahaan menurut Nawawi (2006) terdiri dari lima indikator, yaitu:

1. Kuantitas hasil kerja yang dicapai. Jumlah pekerjaan yang dihasilkan oleh karyawan atau kelompok sebagai persyaratan yang menjadi standar dari sebuah pekerjaan.

2. Kualitas hasil kerja yang dicapai.

Karyawan dapat menghasilkan pekerjaan sesuai persyaratan kualitas yang dituntut dari sebuah pekerjaan.

3. Jangka waktu mencapai hasil kerja.

Suatu pekerjaan harus diselesaikan tepat waktu karena memiliki ketergantungan atas pekerjaan lainnya.

4. Kehadiran di tempat kerja.

Pekerjaan menuntut kehadiran karyawan dalam mengerjakan tugasnya sesuai dengan waktu yang ditentukan.

5. Kemampuan bekerja sama.

Suatu pekerjaan tidak dapat diselesaikan hanya dengan satu karyawan saja, sehingga diperlukan tim untuk menyelesaikan pekerjaan tersebut, sehingga membutuhkan kerja sama antar karyawan.

\section{METODE PENELITIAN}

Penelitian ini dilakukan di Head Office PT. TMMIN selama bulan Oktober 2018 sampai Januari 2019. Responden pada penelitian ini adalah karyawan divisi human resource PT Toyota Motor Manufacturing Indonesia. Jenis data yang digunakan adalah data primer dan data sekunder. Data primer diperoleh dari kuesioner yang dibagikan kepada responden sedangkan data sekunder diperoleh dari internal perusahaan berupa data karakteristik responden dan struktur organisasi pada divisi human resource PT. TMMIN. Total responden pada divisi human resource PT Toyota Motor Manufacturing Indonesia adalah 69 orang. 
Metode pemilihan sampel yang digunakan berdasarkan teknik nonprobability sampling dimana pengumpulan informasi dan pengetahuan dari responden menggunakan cara purposive sampling. Jumlah kuesioner yang disebar pada penelitian ini yaitu 69 kuesioner. Jumlah kuesioner yang kembali adalah 57 kuesioner. Nilai respon rate kuesioner yang diambil pada karyawan divisi human resource PT. Toyota Motor Manufacturing Indonesia adalah 83 persen.

Pengolahan dan analisis data dalam penelitian ini dilakukan dengan uji instrumen, analisis deskriptif dan PLS untuk menganalisis model SEM. Uji instrumen dilakukan untuk mengetahui validitas dan reliabilitas kuesioner. Hal ini dilakukan dengan menguji butir-butir pertanyaan dalam kuesioner yang diberikan kepada responden. Apabila dinyatakan valid, maka pertanyaan tersebut dipakai untuk pembahasan selanjutnya. Pada penelitian ini, analisis data yang digunakan adalah Structural Equation Modeling (SEM) dengan pendekatan partial least square (PLS). PLS adalah model yang berbasis komponen atau varian. Menurut Ghozali (2008), PLS merupakan pendekatan alternatif yang bergeser dari pendekatan SEM yang berbasis kovarian menjadi berbasis varian. Untuk menganalisis penelitian ini dilakukan beberapa tahapan (Santoso, 2011), yaitu membuat model SEM, menyiapkan desain penelitian, identifikasi model dan pengujian model.

Pada penelitian ini, variabel laten eksogen terdiri dari 3 variabel, yaitu keterlekatan karyawan terdiri dari 3 indikator (X1 1 sampai X13), pemberdayaan terdiri dari 4 indikator (X21 sampai $\mathrm{X} 24$ ) dan komitmen organisasi terdiri dari 3 indikator (X31 sampai X33). Variabel laten endogen terdiri dari 1 variabel yaitu kinerja karyawan yang terdiri dari 5 indikator (Y11 sampai Y15). Model SEM pada penelitian ini akan diperlihatkan pada Gambar 1.

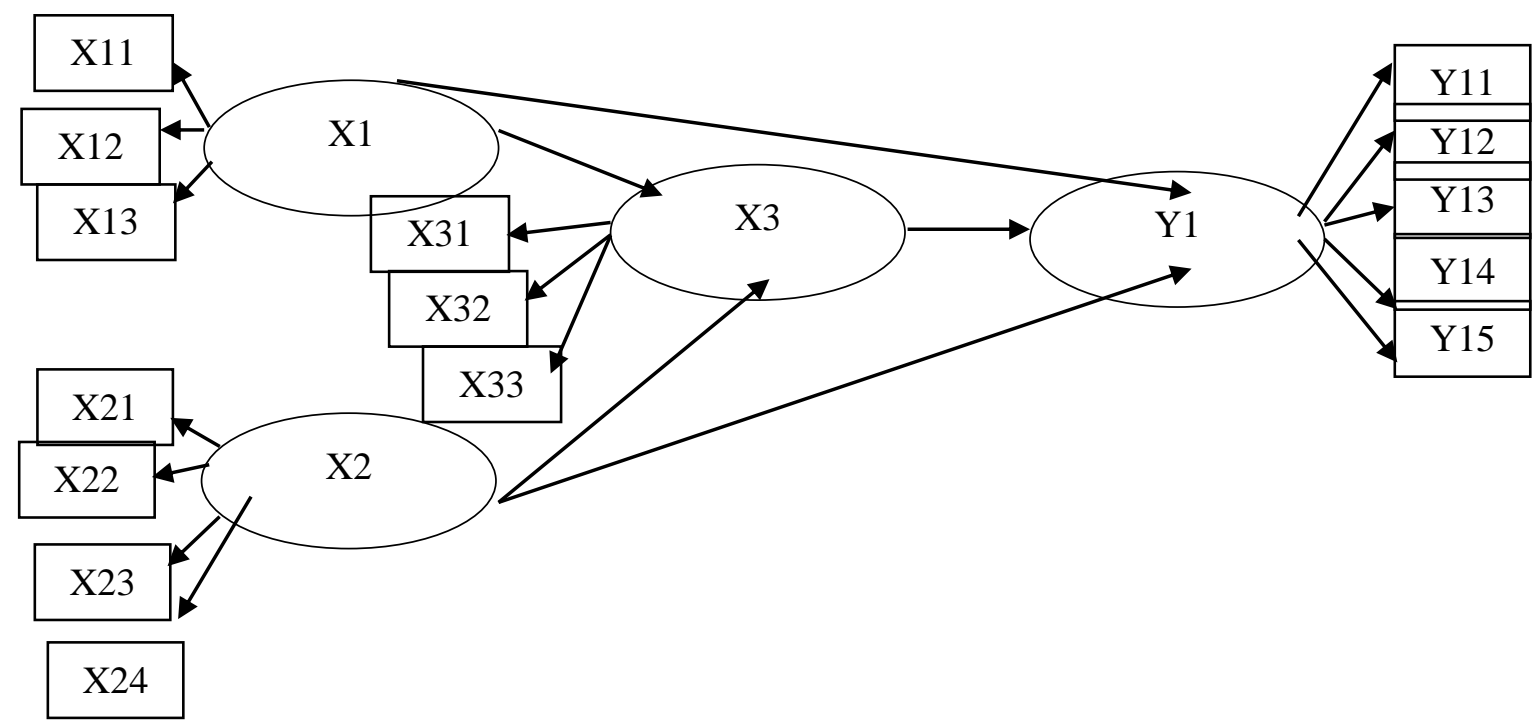

Gambar 1. Model Penelitian 


\section{Adel Christian P Sakeru \\ Aji Hermawan \\ Yunus Triyonggo}

Keterangan:

$\begin{array}{llll}\text { Variabel } & \text { Keterangan } & \text { Variabel } & \text { Keterangan } \\ \text { X11 } & \text { Vigor } & \text { Y11 } & \text { Kuantitas Hasil Kerja Yang Dicapai } \\ \text { X12 } & \text { Dedication } & \text { Y12 } & \text { Kualitas Hasil Kerja Yang Dicapai } \\ \text { X13 } & \text { Absorption } & \text { Y13 } & \text { Jangka Waktu Mencapai Hasil Kerja } \\ \text { X21 } & \text { Makna } & \text { Y14 } & \text { Kehadiran di Tempat Kerja } \\ \text { X22 } & \text { Dampak } & \text { Y15 } & \text { Kemampuan Bekerja Sama } \\ \text { X23 } & \text { Pilihan } & & \\ \text { X24 } & \text { Kemampuan } & \\ \text { X31 } & \text { Afektif } & & \\ \text { X32 } & \text { Normatif } & & \\ \text { X33 } & \text { Kontinuan } & \end{array}$

\section{HASIL DAN DISKUSI}

\section{Karakteristik Responden}

Gambaran umum responden menjelaskan tentang karakteristik responden dalam penelitian ini. Penelitian ini memakai metode distribusi kuesioner pada kantor pusat PT. Toyota Motor Manufacturing Indonesia divisi human resource untuk mengetahui seberapa besar pengaruh keterlekatan karyawan, pemberdayaan dan komitmen organisasi terhadap kinerja karyawan. Sebanyak 57 kuesioner yang telah kembali berisi data karakteristik responden meliputi jenis kelamin, usia, lama bekerja dan pendidikan terakhir. Berikut adalah penjelasan masing-masing karakteristik responden yang disajikan pada Tabel 1.

Berdasarkan Tabel 1, hasil yang diperoleh menunjukkan bahwa karyawan divisi human resource PT. TMMIN didominasi oleh responden yang memiliki jenis kelamin laki-laki dengan persentase 54 persen, sedangkan karyawan dengan jenis kelamin perempuan sebesar 46 persen. Setelah karakteristik berdasarkanjenis kelamin, identitas responden dijelaskan melalui karakteristik berdasarkan usia. Hasil yang diperoleh menunjukkan bahwa karyawan divisi human resource PT. TMMIN didominasi oleh responden yang berusia 41 hingga 50 tahun yaitu sebesar 37 persen. Hasil ini menunjukkan bahwa divisi human resource PT. TMMIN pada umumnya memiliki karyawan dengan pengalaman yang lebih banyak dalam bekerja, sehingga dapat membantu dalam meningkatkan kinerja organisasi. Karakteristik responden selanjutnya dilihat dari berapa lama karyawan bekerja dalam organisasi atau institusi. Hasil yang diperoleh menunjukkan bahwa karyawan divisi human resource PT. TMMIN didominasi oleh responden yang memiliki masa kerja 21 hingga 30 tahun sebesar 42 persen. Kondisi ini menandakan bahwa karyawan pada divisi human resource PT. TMMIN memiliki sifat yang loyal terhadap perusahaan. Karakteristik responden selanjutnya yaitu dilihat dari tingkat 
pendidikan, dimana tingkat pendidikan pada umumnya menjadi basis organisasi atau manajemen untuk menjadi faktor utama dalam merekrut calon karyawan. Hasil menunjukkan bahwa karyawan divisi human resource PT. TMMIN didominasi oleh responden yang memiliki tingkat pendidikan terakhir Strata 1 (S1) yaitu 44 persen. Hasil ini menunjukkan bahwa keberagaman tingkat pendidikan dapat dijadikan bahan evaluasi bagi perusahaan untuk meningkatkan kompetensi karyawannya.

Tabel 1.

Nilai Karakteristik Responden

\begin{tabular}{lc}
\hline \multicolumn{1}{c}{ Karakteristik Responden } & Nilai (\%) \\
\hline Jenis Kelamin & 54 \\
\hline Laki - Laki & 46 \\
Perempuan & \\
\hline Usia (tahun) & 28 \\
\hline $21-30$ & 19 \\
$31-40$ & 37 \\
$41-50$ & 16 \\
$51-60$ & \\
\hline Lama Bekerja (tahun) & 26 \\
\hline $0-5$ & 12 \\
$6-10$ & 16 \\
$11-20$ & 42 \\
$21-30$ & 4 \\
$31-40$ & \\
\hline Pendidikan Terakhir & 26 \\
\hline SMA & 26 \\
Diploma & 44 \\
Sarjana & 4 \\
Magister & \\
\hline
\end{tabular}

\section{Model Hasil Pengolahan}

Berikut ini adalah model hasil pengolahan dengan Smart PLS yang ditampilkan pada Gambar 2. Nilai yang menghubungkan variabel laten ke indikatornya merupakan nilai loading factor, yang mana digunakan untuk menguji validitas. Menurut Ghozali (2008), apabila terdapat indikator yang memiliki nilai loading factor $<0.7$, harus dilakukan kalkulasi kembali terhadap model awal sehingga menghasilkan loading factor seluruh indikator reflektif bernilai > 0.7 sebagai kriteria dari uji validitas konstruk convergent. Model pada Gambar 2 menunjukkan tidak terdapat indikator yang memiliki nilai loading factor $<0.7$ yang berarti indikator yang digunakan sudah menggambarkan variabel laten secara baik.

\section{Model Pengukuran (Outer Model)}

Analisis order pertama adalah analisis yang bertujuan untuk menguji validitas dan reliabilitas masing-masing indikator dari setiap dimensi yang membentuk variabel laten. Validitas indikator terdiri dari dua, yaitu validitas konvergen dan validitas diskriminan. Validitas konvergen dapat dilihat dari nilai average variance extracted (AVE), nilai comunality dan 
Adel Christian P Sakeru

Aji Hermawan

Yunus Triyonggo

nilai outer loading. Sedangkan validitas diskriminan dilihat dari nilai akar kuadrat average variance extracted (AVE), nilai korelasi dan nilai cross loading. Berikut ini adalah hasil pengukuran validitas konvergen dan reliabilitas yang akan ditampilkan pada Tabel 2.

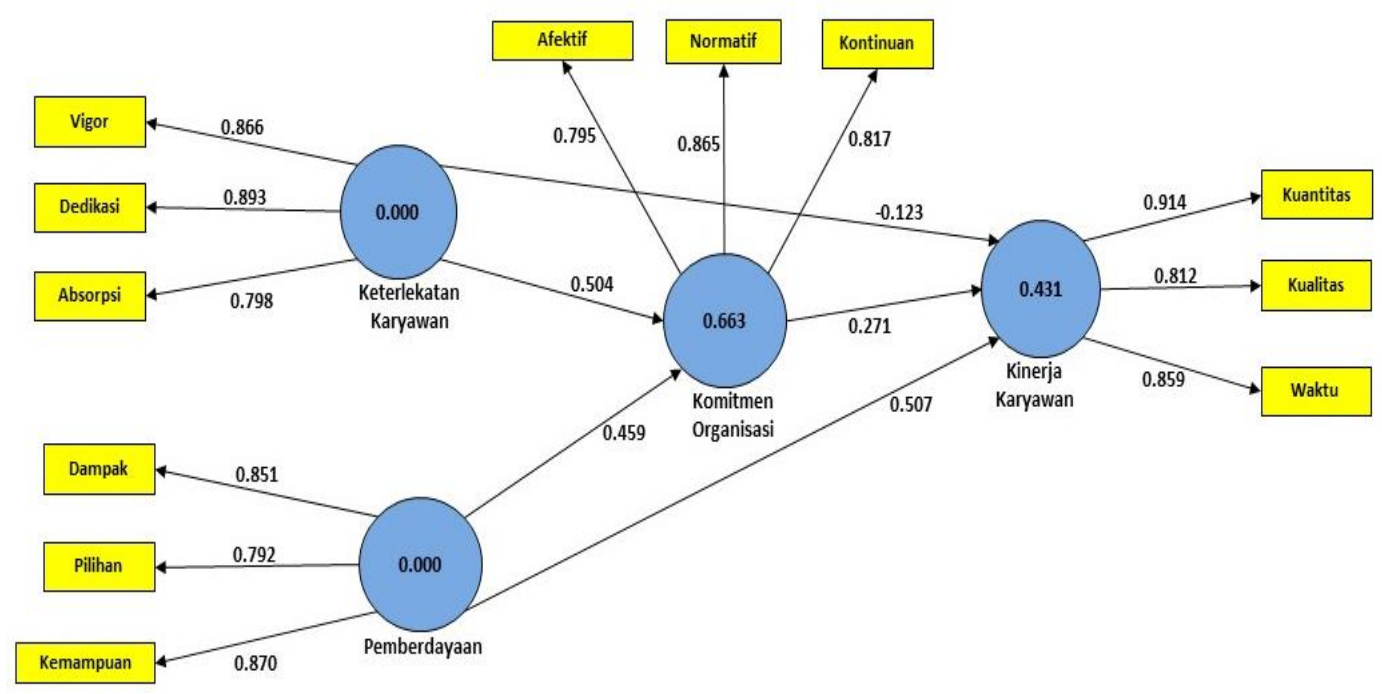

Gambar 2.

Model Hasil Pengolahan

Tabel 2.

Nilai AVE dan Composite Reliability

\begin{tabular}{ccc}
\hline Variabel & AVE & Composite Reliability \\
\hline Keterlekatan Karyawan & 0.7277 & 0.8889 \\
Pemberdayaan & 0.7029 & 0.8763 \\
Komitmen Organisasi & 0.7446 & 0.8972 \\
Kinerja Karyawan & 0.6826 & 0.8656 \\
\hline
\end{tabular}

Tabel 2 menunjukkan nilai AVE dan composite reliability. Model dikatakan baik jika memenuhi syarat validitas dan reliabilitas. Model memiliki validitas yang baik apabila masing-masing variabel laten dengan indikator reflektif memiliki AVE $>0.5$, sementara akan bersifat reliabel jika variabel laten memiliki nilai composite reliability lebih dari 0.7. Hasil analisis menunjukkan nilai AVE dari masing-masing variabel laten memiliki nilai $>0.5$ dan semua konstruk laten memiliki nilai composite reliability lebih dari 0.7 sehingga dapat dikatakan model PLS memenuhi syarat validitas convergent yang baik dan memiliki reliabilitas yang baik, akurat dan konsisten.

Pengujian selanjutnya pada analisis order pertama adalah uji validitas discriminant. Pengujian validitas discriminant dilakukan dengan prinsip bahwa pengukur-pengukur (manifest variabel) konstruk yang berbeda seharusnya tidak berkolerasi tinggi. Salah satu 
cara menguji discriminant validity adalah dengan membandingkan nilai akar dari average variance extracted (AVE) setiap konstruk dengan korelasi antar konstruk dengan konstruk lainnya. Berikut ini akan ditampilkan nilai AVE dan VAVE pada Tabel 3.

\section{Tabel 3.}

Nilai AVE dan $\sqrt{ } \mathrm{AVE}$

\begin{tabular}{ccc}
\hline Variabel & AVE & $\sqrt{ }$ AVE \\
\hline Keterlekatan Karyawan & 0.7277 & 0.8530 \\
Pemberdayaan & 0.7029 & 0.8384 \\
Komitmen Organisasi & 0.7446 & 0.8629 \\
Kinerja Karyawan & 0.6826 & 0.8262 \\
\hline
\end{tabular}

Berdasarkan Tabel 3, diperoleh hasil bahwa nilai akar AVE lebih tinggi terhadap korelasi antar konstruk dengan konstruk lainnya, sehingga dapat dikatakan bahwa model telah memenuhi syarat validitas discriminant.

\section{Model Struktural (Inner Model)}

Dalam menilai model struktural, nilai yang dilihat adalah nilai R-Squares atau nilai koefisien determinan $\left(R^{2}\right)$ untuk setiap variable laten endogen sebagai kekuatan prediksi dari model struktural. Perubahan nilai $\mathrm{R}^{2}$ dapat digunakan untuk menjelaskan pengaruh variabel laten eksogen tertentu terhadap variabel laten endogen apakah mempunyai pengaruh yang substantive. Nilai koefisien determinan $\left(R^{2}\right)$ 0.75, 0.50 dan 0.25 dapat disimpulkan bahwa model kuat, moderate dan lemah. Selain dengan nilai koefisien determinan $\left(R^{2}\right)$, pengukuran model struktural juga dapat dilihat melalui nilai koefisien path atau t-value. Nilai $\mathrm{R}^{2}$ digunakan untuk mengukur tingkat variasi perubahan variabel independen terhadap variabel dependen. Berikut ini disajikan nilai koefisien determinan $\left(R^{2}\right)$ yang dapat dilihat pada Tabel 4.

Tabel 4.

Nilai Koefisien Determinan $\left(R^{2}\right)$

\begin{tabular}{cc}
\hline & Nilai R $^{2}$ \\
\hline Kinerja Karyawan & 0.4306 \\
Komitmen Organisasi & 0.6628 \\
\hline
\end{tabular}

Pada model penelitian ini, terdapat dua variabel laten endogen sehingga nilai koefisien determinan $\left(R^{2}\right)$ dari kinerja karyawan dan komitmen organisasi digunakan untuk mengevaluasi kebaikan model. Berdasarkan hasil pada Tabel 4, diperoleh bahwa nilai koefisien determinan $\left(R^{2}\right)$ kinerja karyawan sebesar 0.4306. Hasil tersebut menyatakan bahwa keragaman variabel kinerja karyawan dapat dijelaskan oleh komitmen organisasi, pemberdayaan dan keterlekatan karyawan sebesar 43.06 persen, sedangkan 56.94 persen lainnya dijelaskan oleh variabel independen lain yang tidak masuk dalam model. Hasil berikutnya adalah nilai koefisien determinan $\left(R^{2}\right)$ komitmen organisasi sebesar 0.6628 . Hasil 
Adel Christian P Sakeru

Aji Hermawan

Yunus Triyonggo

tersebut menyatakan bahwa keragaman variabel komitmen organisasi dapat dijelaskan oleh variabel pemberdayaan dan variabel keterlekatan karyawan sebesar 66.28 persen, sedangkan 33.72 persen lainnya dijelaskan oleh variabel independen lain yang tidak masuk dalam model. Nilai koefisien determinan $\left(R^{2}\right)$ yang diperoleh sudah cukup baik.

\section{Uji Hipotesis}

Model struktural adalah model yang menghubungkan variabel laten eksogenous dengan variabel laten endogenous atau hubungan variabel endogenous dengan variabel endogenous lainnya. Pada penelitian ini, model struktural terkait dengan lima hipotesis penelitian yang mengisyaratkan hubungan kausalitas diantara variabel-variabel laten. Pengujian hipotesis menggunakan statistik uji † dengan kriteria pengambilan keputusan sebagai berikut tolak HO jika † statistik lebih dari 1.96 (nilai † pada alpha 0.05). Berikut ini akan disajikan hasil pengujian hipotesis yang dapat dilihat pada Tabel 5.

Tabel 5.

Hasil Pengujian Hipotesis

\begin{tabular}{lccccc}
\hline & $\begin{array}{c}\text { Original } \\
\text { Sample } \\
(\mathbf{O})\end{array}$ & $\begin{array}{c}\text { Sample } \\
\text { Mean } \\
(\mathbf{M})\end{array}$ & $\begin{array}{c}\text { Standard } \\
\text { Deviation } \\
\text { (STDEV) }\end{array}$ & $\begin{array}{c}\text { Standard } \\
\text { Error } \\
(\text { STERR) }\end{array}$ & $\begin{array}{c}\text { T- } \\
\text { Statistics }\end{array}$ \\
\hline $\mathrm{KLK} \rightarrow \mathrm{KJK}$ & 0.0134 & 0.0063 & 0.0706 & 0.0706 & 0.1902 \\
$\mathrm{P} \rightarrow \mathrm{KJK}$ & 0.6312 & 0.6386 & 0.0533 & 0.0533 & 11.8495 \\
$\mathrm{KLK} \rightarrow \mathrm{KO}$ & 0.5036 & 0.4946 & 0.0678 & 0.0678 & 7.4270 \\
$\mathrm{P} \rightarrow \mathrm{KO}$ & 0.4587 & 0.4616 & 0.0582 & 0.0582 & 7.8787 \\
$\mathrm{KO} \rightarrow \mathrm{KJK}$ & 0.2708 & 0.2700 & 0.0927 & 0.0927 & 2.9219 \\
\hline
\end{tabular}

Hasil analisis pada Tabel 5 menunjukkan bahwa hasil pengujian hipotesis keterlekatan karyawan tidak berpengaruh signifikan terhadap kinerja karyawan karena nilai t hitung lebih kecil dari 1.9500 yaitu sebesar 0.1902, namun hasil analisis menunjukkan keterlekatan karyawan berpengaruh positif terhadap kinerja karyawan yang maknanya adalah semakin baik keterlekatan karyawan maka kinerja karyawan akan meningkat. Keterlekatan karyawan tidak memberikan pengaruh langsung terhadap kinerja karyawan. Menurut Robbins dan Judge (2015), terdapat faktor yang mempengaruhi keterlekatan karyawan dalam sebuah organisasi yaitu organisasi memiliki manajer yang baik, sehingga karyawan akan merasa nyaman. Selain itu adalah karyawan merasa diapresiasi oleh atasannya. Kedua faktor tersebut terkait dengan hubungan baik antara manajer dan karyawan. Hasil penelitian juga sesuai dengan penelitian terdahulu yang dilakukan oleh Joushan et al. (2015) yang menghasilkan bahwa keterlekatan karyawan tidak memberikan pengaruh yang signifikan terhadap kinerja karyawan. Hal ini dapat disebabkan karena kurangnya apresiasi dari atasan kepada karyawannya sehingga menyebabkan hubungan kerjasama dari atasan kepada anggotanya tidak berjalan dengan baik pada divisi human resource PT. TMMIN. Pernyataan tersebut didukung dengan hasil yang didapat bahwa indikator 


\section{Jurnal Manajemen Teori dan Terapan \\ Tahun 12. No. 2, Agustus 2019}

kemampuan kerja sama tidak menjadi indikator yang dapat menjelaskan variabel kinerja karyawan. Hasil penelitian ini berbanding terbalik dengan hasil penelitian terdahulu yaitu penelitian Dajani (2015), serta Ariarni dan Afrianty (2017) yang menyatakan bahwa keterlekatan karyawan memiliki pengaruh yang signifikan dan berpengaruh positif terhadap kinerja karyawan.

Pemberdayaan berpengaruh signifikan terhadap kinerja karyawan karena nilai t hitung lebih besar dari 1.9500 yaitu sebesar 11.8495. Hasil analisis menunjukkan bahwa pemberdayaan berpengaruh positif dan berpengaruh signifikan terhadap kinerja karyawan. Semakin tinggi pemberdayaan karyawan maka kinerja karyawan divisi human resource PT. Toyota Motor Manufacturing Indonesia akan meningkat. Hasil penelitian ini mengkonfirmasi hasil penelitian terdahulu yaitu penelitian Yulianti (2012), Darlis dan Cahayani (2013)serta Suryadewiet al. (2014)yang membuktikan bahwa pemberdayaan memiliki pengaruh yang signifikan dan berpengaruh positif terhadap kinerja karyawan. Hasil ini memperkuat pernyataan Wibowo (2007) yang mengatakan bahwa pemberdayaan merupakan faktor yang sangat mempengaruhi kinerja karyawan. Pemberdayaan mendorong karyawan untuk lebih terlibat dalam membuat keputusan, dengan demikian akan dapat meningkatkan kemampuan, rasa memiliki serta meningkatkan rasa tanggung jawab yang diberikan. Pendapat tersebut dipertegas oleh Sedarmayanti (2007) yang menyatakan bahwa pemberdayaan dapat meningkatkan kinerja karyawan melalui kegiatan perubahan dan pengembangan karyawan berupa kemampuan karyawan, kepercayaan di lingkungan kerja, wewenang dan tanggung jawab karyawan dalam bekerja. Pemberdayaan karyawan memberikan pengaruh yang signifikan karena karyawan pada divisi human resource PT. TMMIN benarbenar telah memahami tanggung jawab mereka atas pekerjaan tersebut dan mampu memecahkan permasalahan serta membuat keputusan sesuai dengan wewenang mereka. Selain itu, pemberdayaan karyawan berpengaruh terhadap kinerja karyawan karena kompetensi yang dimiliki dan kepercayaan diri yang dimiliki karyawan membantu dalam penyelesaian masalah yang ditemui dalam pekerjaan.

Keterlekatan karyawan berpengaruh signifikan terhadap komitmen organisasi karena nilai † hitung lebih besar dari 1.9500 yaitu sebesar 7.4270. Hasil analisis menunjukkan bahwa keterlekatan karyawan berpengaruh positif dan berpengaruh signifikan terhadap komitmen organisasi. Semakin tinggi keterlekatan karyawan maka komitmen organisasi divisi human resource PT. Toyota Motor Manufacturing Indonesia akan meningkat. Hasil penelitian ini mengkonfirmasi hasil penelitian terdahulu yaitu penelitian Saks (2006), Indayati et al. (2012) dan Prerana (2017) yang membuktikan bahwa keterlekatan karyawan memiliki pengaruh signifikan dan berpengaruh positif terhadap komitmen organisasi. Hasil ini memperkuat pernyataan Swaminathan dan Aramvalarthan (2013) yang mengemukakan bahwa 
Adel Christian P Sakeru

Aji Hermawan

\section{Yunus Triyonggo}

pengaruh tersebut dapat mengakibatkan karyawan bekerja dengan baik dalam organisasi sehingga organisasi dapat tumbuh dan berkembang. Keterlekatan karyawan memberikan pengaruh yang signifikan terhadap komitmen organisasi karena karyawan pada divisi human resource PT. TMMIN saat bekerja seakan lupa terhadap lingkungan pekerjaannya. Selain itu, karyawan juga senang saat kondisi sibuk bekerja sehingga mengakibatkan karyawan terbawa suasana saat bekerja. Berdasarkan kondisi-kondisi tersebut, maka dapat dikatakan bahwa karyawan divisi human resource PT. TMMIN sangat berkonsentrasi dalam mengerjakan tugasnya. Karyawan yang berkonsentrasi dalam bekerja, menandakan bahwa karyawan telah memiliki komitmen terhadap pekerjaan dan organisasinya.

Pemberdayaan berpengaruh signifikan terhadap komitmen organisasi karena nilai t hitung lebih besar dari 1.9500 yaitu sebesar 7.8787. Hasil analisis menunjukkan bahwa pemberdayaan berpengaruh positif dan berpengaruh signifikan terhadap komitmen organisasi. Semakin meningkat pemberdayaan maka komitmen organisasi divisi human resource PT. Toyota Motor Manufacturing Indonesia akan meningkat. Hasil penelitian ini mengkonfirmasi hasil penelitian terdahulu yaitu penelitian Suhermin (2012), Merry (2017) dan Mahiri (2017) yang membuktikan bahwa pemberdayaan memiliki pengaruh yang signifikan dan berpengaruh positif terhadap komitmen organisasi. Hasil ini memperkuat pernyataan Laschinger et al. (2001) bahwa pemberdayaan yang tinggi dalam sebuah organisasi akan meningkatkan komitmen karyawan terhadap organisasinya. Karyawan yang diberdayakan dengan baik oleh perusahaan, tidak akan memiliki keinginan untuk keluar dari perusahaan dan lebih memilih untuk tetap berkomitmen dengan baik terhadap organisasinya. Hal ini dapat menjadi modal dasar bagi perusahaan untuk mendorong produktivitas yang tinggi. Pendapat tersebut dipertegas oleh Dewi (2015) yang menyatakan bahwa pemberdayaan dapat meningkatkan komitmen organisasi melalui wewenang dan tanggung jawab karyawan dalam bekerja. Pemberdayaan karyawan memberikan pengaruh yang signifikan terhadap komitmen organisasi karena karyawan pada divisi human resource PT. TMMIN merasa telah diberlakukan adil, baik secara prosedur, interaksi maupun tugas dalam organisasi. Selain itu, organisasi juga telah menjalankan kebijakan pemberdayaan karyawan dengan baik. Pemberdayaan juga berkontribusi terhadap komitmen organisasi melalui pemberian akses dan dorongan kepada individu agar organisasi lebih mendayagunakan sumber daya yang tersedia.

Komitmen organisasi berpengaruh signifikan terhadap kinerja karyawan karena nilai t hitung lebih besar dari 1.9500 yaitu sebesar 2.9219. Hasil analisis menunjukkan bahwa komitmen organisasi berpengaruh signifikan dan positif terhadap kinerja karyawan. Semakin meningkat komitmen karyawan terhadap organisasinya maka kinerja karyawan divisi human resource PT. Toyota Motor Manufacturing Indonesia akan meningkat. Hasil analisis ini juga 
menunjukkan bahwa keterlekatan karyawan dan pemberdayaan memberikan pengaruh tidak langsung terhadap kinerja karyawan melalui komitmen organisasi. Penelitian ini mengkonfirmasi hasil penelitian terdahulu yaitu penelitian Mahennoko (2011), Tolentino (2013) serta Fitriastuti (2011) yang menyatakan bahwa komitmen organisasi memiliki pengaruh yang signifikan dan berpengaruh positif terhadap kinerja karyawan. Karyawan yang memiliki komitmen organisasi yang tinggi menandakan bahwa karyawan tersebut memiliki tanggung jawab yang penuh terhadap pekerjaannya dan dapat melakukan fungsi kerjanya tanpa meminta bantuan dari orang lain. Karyawan dengan komitmen yang tinggi mampu menunjukkan kinerja optimal, sehingga mampu memberikan kontribusi yang berarti terhadap organisasinya. Karyawan tersebut akan terus menjadi anggota dalam organisasi karena merasa dirinya harus berada dalam organisasi tersebut. Pernyataan ini sesuai dengan kondisi divisi human resource PT. TMMIN, bahwa dari karakteristik responden melalui indikator lama bekerja menghasilkan jika divisi human resource PT. TMMIN didominasi oleh karyawan yang bekerja selama 21 tahun hingga 30 tahun. Kondisi ini akan mempengaruhi karyawan untuk berusaha terus meningkatkan kinerjanya dengan tujuan kemajuan organisasi.

Berdasarkan hasil yang diperoleh pada penelitian ini, maka variabel yang paling memberikan pengaruh signifikan terhadap peningkatan kinerja karyawan adalah variabel pemberdayaan. Variabel pemberdayaan memberikan pengaruh terhadap peningkatan kinerja karyawan baik secara langsung ataupun melalui variabel komitmen organisasi. Hasil ini membuat peningkatan kinerja karyawan dapat ditingkatkan dengan fokus terhadap peningkatan pemberdayaan karyawan divisi human resource PT. Toyota Motor Manufacturing Indonesia. Variabel pemberdayaan pada penelitian ini dijelaskan oleh indikator-indikator pembentuknya yaitu kemampuan, dampak dan pilihan. Hal tersebut membuat divisi human resource PT. Toyota Motor Manufacturing Indonesia perlu memperhatikan:

1. Indikator kemampuan atau kompetensi merupakan indikator yang paling menjelaskan pemberdayaan pada divisi human resource PT. Toyota Motor Manufacturing Indonesia. Ini dapat dilihat dari nilai loading factor tertinggi yaitu sebesar 0.870 . Kemampuan atau kompetensi karyawan dapat ditingkatkan dengan melakukan pelatihan dan pengembangan karyawan yang sesuai dengan kebutuhan karyawan. Kompetensi yang sesuai akan membantu karyawan dalam menyelesaikan pekerjaannya. Karyawan akan merasa yakin bahwa hasil kerjanya akan memberikan dampak yang besar dalam organisasinya. Evaluasi terhadap kegiatan pelatihan dan pengembangan juga menjadi penting karena dengan adanya evaluasi, maka kekurangan dari program ini dapat diketahui. 
Adel Christian P Sakeru

Aji Hermawan

Yunus Triyonggo

2. Indikator dampak juga merupakan indikator yang menjelaskan pemberdayaan pada divisi human resource PT. Toyota Motor Manufacturing Indonesia. Ini dapat dilihat dari nilai loading factor sebesar 0.851. Dampak yang diberikan karyawan dalam bekerja dapat ditingkatkan dengan melakukan kegiatan briefing harian. Briefing harian bertujuan untuk membahas rencana kerja dan evaluasi terhadap pekerjaan yang telah diselesaikan. Briefing dapat dilakukan sebelum pekerjaan dimulai ataupun setelah pekerjaan selesai. Briefing digunakan untuk membahas mengenai rencana kerja divisi yang akan diselesaikan. Pemaparan terhadap rencana kerja akan membuat karyawan dapat mulai menentukan cara yang akan digunakan dalam menyelesaikan rencana kerja. Selain pemaparan rencana kerja, evaluasi kerja perlu dilakukan untuk mengevaluasi pencapaian dari sebuah pekerjaan. Dengan mengetahui pencapaian kerja karyawan, maka karyawan dapat melakukan improvement terhadap pekerjaan berikutnya.

3. Indikator pilihan merupakan indikator yang juga menjelaskan pemberdayaan pada divisi human resource PT. Toyota Motor Manufacturing Indonesia. Ini dapat dilihat dari nilai loading factor tertinggi yaitu sebesar 0.792. Pilihan dalam bekerja perlu diberikan kepada karyawan agar karyawan dapat mencapai kinerja terbaiknya sesuai dengan cara yang digunakan. Pilihan dalam bekerja dapat diberikan kepada karyawan melalui kegiatan coaching and clinic Kegiatan yang dimaksud adalah seorang manager atau supervisor rutin (secara berkala) melakukan komunikasi secara personal dengan karyawannya. Manager dapat dengan langsung memberikan wewenang kepada anggotanya. Pemberian wewenang secara langsung oleh manager menandakan bahwa manager memiliki kepercayaan terhadap karyawan. Kepercayaan tersebut akan dapat meningkatkan peran karyawan dalam organisasinya. Karyawan menjadi semakin aktif dan akan mengelvarkan kemampuan terbaiknya dalam bekerja. Pada akhirnya kinerja masing-masing karyawan akan dapat memberikan pengaruh yang baik bagi kinerja organisasi atau divisi.

\section{SIMPULAN}

Hasil dari penelitian ini menunjukkan bahwa keterlekatan karyawan tidak berpengaruh signifikan terhadap kinerja karyawan. Hal ini menunjukkan bahwa keterlekatan karyawan tidak memberikan pengaruh langsung terhadap kinerja karyawan namun keterlekatan karyawan memberikan pengaruh tidak langsung yang signifikan terhadap kinerja karyawan melalui komitmen organisasi. Peningkatan keterlekatan karyawan akan meningkatkan komitmen organisasi yang menghasilkan peningkatan kinerja karyawan di divisi human resource PT. Toyota Motor Manufacturing Indonesia. Hasil berikutnya menunjukkan pemberdayaan berpengaruh signifikan terhadap komitmen organisasi dan kinerja karyawan. Hal ini menunjukkan bahwa pemberdayaan memberikan pengaruh langsung 
terhadap kinerja karyawan dan juga memberikan pengaruh tidak langsung terhadap kinerja karyawan melalui komitmen organisasi. Peningkatan pemberdayaan akan meningkatkan komitmen organisasi yang menghasilkan peningkatan kinerja karyawan di divisi human resource PT. Toyota Motor Manufacturing Indonesia.

Keterbatasan pada penelitian ini adalah peneliti kesulitan dalam mengambil data dikarenakan memang kondisi perusahaan yang sedang padat dalam aktivitas organisasi. Berdasarkan hasil penelitian yang diperoleh, maka saran yang dapat diajukan untuk penelitian selanjutnya adalah memperluas objek penelitian pada satu perusahaan, bukan hanya pada satu divisi saja. Selain itu juga dapat mempertimbangkan untuk melakukan analisis dengan metode Analytical Hierarchy Process (AHP) untuk merumuskan strategi apa yang diperlukan untuk meningkatkan kinerja karyawan. Penelitian selanjutnya juga dapat mempertimbangkan faktor-faktor lain yang dapat berpengaruh terhadap kinerja karyawan seperti kepuasan kerja, budaya organisasi atau gaya kepemimpinan.

\section{DAFTAR PUSTAKA}

Abadi, M. V., and Chegini. 2013. The relationship between employees empowerment with job satisfaction in Melli Bank of Guilan Province. Arabian Journal of Business and Management Review. 2(12): 71-79.

Allen, N. J., and Meyer, J. P. 1990. The Measurement and Antecedents of Affective, Continuance and Normative Commitment to The Organization. Journal of Occupational Psychology 63: 1-18.

Ariarni, N., and Tri, W. A. 2017. Pengaruh Perceived Organizational Support terhadap Kinerja Karyawan dengan Employee Engagement Sebagai Variabel Intervening. Jurnal Administrasi Bisnis 50 (4): 169-177.

Batliwala, S. 2007. Taking the power out of empowerment an experiential account. Development in Practice. 17(4-5): 557-565.

Boudrias, J. S., LuC, B., Andre, S., Patrick, P., Alexandre, J., and Gerlanda, C. 2010. Empowering employees: the moderating role of perceived organisational climate and justice. Canadian Jornal of Behavioural Science. 42(4): 201-211.

Chughtai, A. A., and Zafar, S. 2006. Antecedents and consequences of organizational commitment among Pakistani University teachers. Applied HRM Research. 11(1): 3964.

Dajani, M. A. 2015. The Impact of Employee Engagement on Job Performance and Organisational Commitment in the Egyptian Banking Sector. Journal of Business and Management Sciences 3 (5): 138-147. 
Adel Christian P Sakeru

Aji Hermawan

Yunus Triyonggo

Fitriastuti, T. 2011. Pengaruh Tipe Kepemimpinan Pada Persepsi Politik dan Outcomes Organisasional dengan Ingrasiasi Sebagai Variabel Pemoderisasi. Jurnal Siasat Bisnis. 15 (2): 229-247.

Ghozali, I. 2008. Structural Equation Modeling, Metode Alternatif dengan Partial Least Square. Semarang (ID): Universitas Diponegoro.

Indayati, N., Armanu. T., and Rofiaty. 2012. Pengaruh Keterlibatan Karyawan, Budaya Organisasi dan Gaya Kepemimpinan terhadap Komitmen Organisasional dalam Meningkatkan Kinerja Karyawan (Studi pada Universitas Brawijaya). Jurnal Aplikasi Manajemen 10 (2): 344-356.

Joushan, S. A., Muhammad, S., and Lindawati, K. 2015. Pengaruh Budaya Organisasi dan Employee Engagement Terhadap Kinerja Karyawan pada PT. PLN (Persero) Area Bekasi. Jurnal Aplikasi Manajemen 13(4): 697-703.

Kreitner, R., and Kinicki, A. 2010. Organizational Behavior (9th Ed). New York: McGraw Hill.

Laschinger, H. K. S., Finegan, J., dan Shamian, J. 2001a. The impact of workplace empowerment, organizational trust on staff nurses's work satisfaction and organizational commitment. Health Care Manage Rev 26 (3): 7-23.

Luthans, F. 2007. Organizational Behavior (9th Ed). Boston: McGraw Hill.

Maarif, M. S., and Kartika, L. 2013. Manajemen Kinerja Sumber Daya Manusia: Implementasi Menuju Organisasi Berkelanjutan. Bogor(ID): IPB Press.

Macey, W. H., and Schneider, B. 2008. The meaning of employee engagement. Industrial and Organizational Psychology. 1 (1): 3-30.

Mahiri, E. A. 2017. Pengaruh Pemberdayaan Karyawan Terhadap Komitmen Organisasional Pada Karyawan Perusahaan Daerah Air Minum (PDAM) Kantor Pusat Majalengka. Jurnal IImiah Manajemen dan Akuntansi 4(2): 108-114.

Mangkunegara, A. P. 2006. Evaluasi Kinerja Sumber Daya Manusia Perusahaan. Bandung (ID): PT. Refika Aditama.

Mangkunegara, A. P. 2007. Manajemen Sumber Daya Manusia. Bandung(ID): PT. Remaja Rosida Karya.

Mangkuprawira, T. B. S., and Hubeis. 2007. Manajemen Mutu Sumber Daya Manusia. Bogor (ID): Ghalia Indonesia.

Mangkuprawira, T. B. S. 201 1. Manajemen Sumber Daya Manusia Strategik. Bogor(ID): Ghalia Indonesia.

Nawawi, H. 2006. Evaluasi dan Manajemen Kinerja di Lingkungan Perusahaan dan Industri. Yogyakarta (ID): Gadjah Mada University Press.

Noe, R., Hollenbeck, J., Gerhart, B., and Wright, P. 2003. Human Resource Management: Gaining a Competitive Advantage. $4^{\text {th }}$ Ed. Boston(US): McGraw Hill.

Prerana. 2017. Effect of Employee Engagement on Organizational Commitment. Indian Journal of Commerce and Management Studies 8(2): 101-108. 
Rivai, V. 2005. Manajemen Sumber Daya Manusia untuk Perusahaan. Jakarta (ID): PT. Raja Grafindo Persada.

Robbins, S. P., and Judge, T. A. 2011 . Organizational Behavior (14 th Ed). New Jersey: Pearson.

Robbins, S. P., and Judge, T. A. 2015. Organizational Behavior (16 th Ed). New Jersey: Pearson.

Santoso, S. 2011. Structural Equation Modeling (SEM) Konsep dan Aplikasi dengan AMOS 18. Jakarta (ID): PT. Elex Media Komputindo.

Schaufeli, W. B., Salanova, M. M., Gonzales, R., and Bakker, A. B. 2002. The Measurement of Engagement and Burnout: A Two Sample Confirmatory Factor Analytic Approach. Journal of Happiness Studies 3: 71-92.

Simanjuntak, P. J. 2011. Manajemen dan Evaluasi Kinerja. Jakarta(ID): Lembaga Penerbit Fakultas Ekonomi Universitas Indonesia.

Sinambela, L. 2012. Kinerja Pegawai: Teori, Pengukuran dan Implikasi. Yogyakarta(ID): Graha IImu.

Sirait, J. T. 2006. Memahami Aspek-Aspek Pengelolaan Sumber Daya Manusia dalam Organisasi. Jakarta (ID): Grasindo.

Spreitzer, G. M. 1995. Psychological Empowerment In The Workplace: Dimensions, Measurement and Validation. Academy of Management Journal 38(5): 1442-1465.

Spreitzer, G. M. 1996. Social Structural Characteristic of Psychological Empowerment. Academy of Management Journal 39(2): 484-504.

Suhermin. 2012. Pemberdayaan Kerja Profesional Sebagai Mediasi Dukungan Organisasi dan Pertukaran Pemimpin-Anggota (LMX) Terhadap Komitmen Organisasional. Jurnal Ekonomi dan Keuangan 16 (2): 209-229.

Swaminathan, J., and Aramvalarthanw, S. 2013. Employee engagement of managerial staff in hospitals-an Indian pilot study. Journal of Business and Management 1 (3): 166-174.

Tolentino, R. C. 2013. Organizational Commitment dan Job Performance of The Academic and Administrative Personel. International Journal of Information Technology and Business Management 15 (1): 51-60. 